\title{
Role of p53 and ki-67 in sebaceous neoplasms
}

\author{
Jessica B. Matildes-Mariscal*, Luis M. Moreno-López, Alejandro K. Márquez-Ramírez, and \\ Patricia Mercadillo-Pérez \\ Dematopathology Service, Hospital General de México “Dr. Eduardo Liceaga”, Mexico City, Mexico
}

\begin{abstract}
Introduction: Histologically speaking, architectural, and cytological features help enable the differentiation between sebaceous carcinoma and benign sebaceous lesions; occasionally, these features are insufficient to determine the benign or malignant nature of a lesion. Objective: The objective of the study was to determine p53 and Ki-67 expressions in benign sebaceous lesions and sebaceous carcinoma. Materials and methods: Analytical, observational, cross-sectional, and retrospective study conducted on a number of cases of sebaceous hyperplasia, sebaceous adenoma, sebaceoma, and sebaceous carcinoma that were diagnosed at the Dermatology Service of General Hospital of Mexico "Dr. Eduardo Liceaga."This included the determination of epidemiological, clinical, histopathological, and immunohistochemical features. In addition, descriptive and bivariate statistics were performed. Results: Thirty-six cases of sebaceous lesions were included: thirteen (36.1\%) cases of hyperplasia, eight (22.2\%) cases of adenoma, five (13.9\%) cases of sebaceoma, and ten (27.8\%) cases of carcinomas. The median age was $57.5+15.66$ years. Males were mostly affected $(52.8 \%)$ and the most frequent topography was the face (91.7\%). Sebaceous carcinomas exhibited the following traits: asymmetry $(p=0.006)$, non-circumscribed lesion $(p<0.0001)$, ulceration ( $p=0.024)$, nuclear atypia $(p<0.0001)$, individual necrosis $(p=0.003)$, squamous metaplasia $(p=0.017)$, and higher mitotic index $(p=0.005)$. Sebaceous carcinomas had a higher percentage of $p 53$ and Ki-67 expression compared to benign sebaceous lesions ( $p=0.001$ and $p=0.001$, respectively) and more frequently expressed $p 53>10 \%$ and Ki-67 $>25 \%(p<0.0001$ and $p<0.0001$, respectively). Conclusion: $p 53$ expression $>10 \%$ and Ki-67 expression $>25 \%$ are suggestive of a sebaceous carcinoma diagnosis.
\end{abstract}

Key words: Sebaceous adenoma. Sebaceoma. Sebaceous carcinoma. P53. Ki-67.

\section{Introduction}

Sebaceous neoplasms include benign lesions such as sebaceous hyperplasia, sebaceous adenoma and sebaceoma, and malignant lesions such as sebaceous carcinoma $^{1-3}$. The latter is a rare tumor, with a prevalence between $6.4 \%$ and $9.7 \%$ among malignant eyelid tumours ${ }^{4,5}$. Metastasis occurs in $14-28 \%$ of cases with a specific mortality rate of $30 \%$. Thus, this diagnosis has an impact on the patient's treatment and prognosis.
Histologically speaking, the identification of sebaceous tumors is based on the architectural and cytological features of the lesion. These features, however, may be somewhat insufficient to make a conclusion on the benign or malignant nature of a neoplasm, especially when biopsy samples are small, incomplete, or from difficult areas such as the eyelid ${ }^{7-12}$. Immunomarkers that could be useful for such differentiation have been investigated ${ }^{13-16}$. The aim of this study was to determine p53 and $\mathrm{Ki}-67$ expressions in benign sebaceous lesions and sebaceous carcinomas.

\section{Correspondence:}

*Jessica B. Matildes-Mariscal

E-mail: dra.matildes@gmail.com
Date of reception: 04-12-2019

Date of acceptance: 26-03-2020

DOI: 10.24875/HGMX.20000090
Available online: 12-11-2020 Rev Med Hosp Gen Mex. 2020;83(4):147-152 www.hospitalgeneral.mx 0185-1063/@ 2020 Sociedad Médica del Hospital General de Mexico. Published by Permanyer. This is an open access article under the CC BYNC-ND license (http://creativecommons.org/licenses/by-nc-nd/4.0/) 


\section{Materials and methods}

An analytical, observational, cross-sectional and retrospective study was conducted. Sebaceous hyperplasia, sebaceous adenoma, sebaceoma and sebaceous carcinomas diagnosed between January 1975 and March 2019 in the Dermatopathology Service of the General Hospital of Mexico "Dr. Eduardo Liceaga" were included. Age, gender, topography, and time of evolution were determined, as well as asymmetry, circumscribed lesion, ulceration, nuclear atypia, mass necrosis, individual necrosis, pagetoid spread, squamous metaplasia, lymphovascular invasion, perineural invasion, and mitotic index (number of mitoses in ten high-power fields) of the lesions. The percentage of p53 and Ki-67 expressions was recorded and an expression lower or higher than $10 \%$ for p53 and lower or higher than $25 \%$ for Ki-67 were used as cutoff points. The data analysis used both the MS Excel and SPSS (Statistical Package for the Social Sciences, IBM SPSS Statistics, V.23.0) software. Descriptive statistics (range, mean, median, standard deviation, and percentages) and inferential statistics (Mann-Whitney U-test, Student's t-test, Chi-square, or Fisher's exact test) were performed. $p<0.05$ was considered a significant difference.

\section{Results}

Thirty-six cases were included: thirteen $(36.1 \%)$ cases of sebaceous hyperplasia, eight $(22.2 \%)$ cases of sebaceous adenoma, five (13.9\%) cases of sebaceo$\mathrm{ma}$, and ten $(27.8 \%)$ cases of sebaceous carcinoma. The average age of the patients was $57.5 \pm 15.66$ years, being more frequent in males than in females $(52.8 \%$ vs. $47.2 \%)$. The most frequent topography was the face $(91.7 \%)$, followed by the scalp (5.6\%) and the periocular region (2.8\%). The median evolution was 36 months (range: 4-480 months). Comparing benign neoplasms with sebaceous carcinoma, a statistically significant difference in gender was observed, with sebaceous carcinoma being more frequent in males $(38.5 \%$ vs. $90 \%$; $p=0.008$ ). Likewise, a more rapid evolution was found in sebaceous carcinoma (median $=36$ months, range: 6-36 months vs. median= 36 months, and range: $4-480$ months, $p=0.025$ ).

In relation to histopathology, sebaceous carcinoma was often found present with the following features: asymmetry ( $11.5 \%$ vs. $60 \%, p=0.006)$, non-circumscribed lesion ( $0 \%$ vs. $60 \%, p<0.0001)$, ulceration $(11.5 \%$ vs. $50 \%$, $p=0.024)$, nuclear atypia ( $3.8 \%$ vs. $100 \%, p<0.0001)$, individual necrosis ( $3.8 \%$ vs. $50 \%, p=0.003$ ), squamous metaplasia ( $0 \%$ vs. $30 \%, p=0.017)$, and higher mitotic index ( 0 vs. 5.5 mitosis in 10 fields, $p=0.005$ ) (Table 1).

Sebaceous carcinoma showed a higher percentage of p53 expression compared to benign lesions (median $=10 \%$, range $0-80 \%$ vs. median $=0 \%$, range: $0-5 \%, p=0.001$ ), and the latter more frequently expressed p53 < 10\% (100\% vs. $30 \%, p<0.0001)$ (Table 2, Figs. 1 and 2). As for Ki-67 expression, sebaceous carcinoma displayed a higher Ki-67 expression percentage compared to benign lesions (median $=35 \%$, range $5-80 \%$ vs. median $=5 \%$, range: $0-30 \%, p<0.0001)$. Accordingly, it was observed that these showed a higher frequency of Ki-67 expression $<25 \%$ in comparison with sebaceous carcinoma (30\% vs. $96.2 \%, p=0.009$ ) (Table 2) (Figs. 1 and 3).

\section{Discussion}

Sebaceous carcinoma was prevalent predominantly in males ( $90 \%$ of cases) and more often extraocular (90\% of tumors), in contrast to what is reported by other authors ${ }^{1-4,7,17-19}$. When compared with benign sebaceous lesions, it showed a shorter-term evolution. From a clinical perspective, this is of particular importance when making a presumptive clinical diagnosis. The histological features that made it possible to differentiate sebaceous carcinomas from benign sebaceous lesions were similar to those reported in the literature ${ }^{19-22}$.

Cabral et al. ${ }^{8}$ suggested that immunohistochemistry should be performed in cases of sebaceous lesions with histological features that prevent their classification as benign or malignant, or in superficial biopsies of the eyelid where it is recommendable to avoid a second biopsy due to its significant morbidity. Ki-67 and p53 were the two immunocytochemical markers used for such differentiation.

Tumor suppressor gene tumor protein 53 (TP53) is involved in stopping the cell cycle and activating apoptosis, preventing uncontrolled cell growth. Mutations of this gene result in defective DNA repair and have been linked to the pathogenesis of some malignancies ${ }^{23-34}$. When this gene is mutated, it encodes a mutated TP53 protein that tends to accumulate in the cell nuclei, making its detection possible by immunohistochemistry ${ }^{23,24,26-}$ 29. In this article, we found that sebaceous carcinoma presented a higher percentage of p53 expression 
Table 1. Histopathological features of benign sebaceous lesions compared to sebaceous carcinoma

\begin{tabular}{|c|c|c|c|}
\hline Feature & Benign sebaceous lesions $n=26 * * *$ & Sebaceous carcinoma $n=10$ & p \\
\hline $\begin{array}{l}\text { Asymmetry } \\
\text { Yes } \\
\text { No }\end{array}$ & $\begin{array}{c}n(\%) \\
3(11.5) \\
23(88.5)\end{array}$ & $\begin{array}{l}n(\%) \\
6(60) \\
4(40)\end{array}$ & 0.006 \\
\hline $\begin{array}{l}\text { Circumscribed } \\
\text { Yes } \\
\text { No }\end{array}$ & $\begin{array}{c}26(100) \\
0(0)\end{array}$ & $\begin{array}{l}4(40) \\
6(60)\end{array}$ & $<0.0001$ \\
\hline $\begin{array}{l}\text { Ulceration } \\
\text { Yes } \\
\text { No }\end{array}$ & $\begin{array}{c}3(11.5) \\
23(88.5)\end{array}$ & $\begin{array}{l}5(50) \\
5(50)\end{array}$ & 0.024 \\
\hline $\begin{array}{l}\text { Nuclear atypia } \\
\text { Yes } \\
\text { No }\end{array}$ & $\begin{array}{c}1(3.8) \\
25(96.2)\end{array}$ & $\begin{array}{c}10(100) \\
0(0)\end{array}$ & $<0.0001$ \\
\hline $\begin{array}{l}\text { Mass necrosis } \\
\text { Yes } \\
\text { No }\end{array}$ & $\begin{array}{c}0(0) \\
26(100)\end{array}$ & $\begin{array}{l}1(10) \\
9(90)\end{array}$ & 0.278 \\
\hline $\begin{array}{l}\text { Individual necrosis } \\
\text { Yes } \\
\text { No }\end{array}$ & $\begin{array}{c}1(3.8) \\
25(96.2)\end{array}$ & $\begin{array}{l}5(50) \\
5(50)\end{array}$ & 0.003 \\
\hline $\begin{array}{l}\text { Pagetoid spread } \\
\text { Yes } \\
\text { No }\end{array}$ & $\begin{array}{c}0(0) \\
26(100)\end{array}$ & $\begin{array}{c}0(0) \\
10(100)\end{array}$ & - \\
\hline $\begin{array}{l}\text { Squamous metaplasia } \\
\text { Yes } \\
\text { No }\end{array}$ & $\begin{array}{c}0(0) \\
26(100)\end{array}$ & $\begin{array}{l}3(30) \\
7(70)\end{array}$ & 0.017 \\
\hline $\begin{array}{l}\text { Lymphovascular invasion } \\
\text { Yes } \\
\text { No }\end{array}$ & $\begin{array}{c}0(0) \\
26(100)\end{array}$ & $\begin{array}{c}0(0) \\
10(100)\end{array}$ & - \\
\hline $\begin{array}{l}\text { Perineural invasion } \\
\text { Yes } \\
\text { No }\end{array}$ & $\begin{array}{c}0(0) \\
26(100)\end{array}$ & $\begin{array}{c}0(0) \\
10(100)\end{array}$ & - \\
\hline Mitotic index * & $0(0-4)$ & $5.5(0-28)$ & 0.005 \\
\hline${ }^{*}$ median (range) & & & \\
\hline
\end{tabular}

*** Sebaceous hyperplasia, sebaceous adenoma and sebaceoma

Table 2. Immunohistochemical features of benign sebaceous lesions compared to sebaceous carcinoma

\begin{tabular}{|l|c|c|c|}
\hline Immunomarker & Benign sebaceous lesions $\mathbf{n = 2 6 * *}$ & Sebaceous carcinoma $\mathbf{n = 1 0}$ & $\mathbf{p}$ \\
\hline Percentage of $\mathrm{p} 53^{*}$ expression & $0(0-5)$ & $10(0-80)$ & 0.001 \\
\hline $\begin{array}{l}\text { p53 expression }<10 \% \\
\text { yes } \\
\text { no }\end{array}$ & $26(100)$ & $3(30)$ & $<0.0001$ \\
\hline $\begin{array}{l}\text { Percentage of Ki-67* expression } \\
\text { Ki-67 expression }<25 \% \\
\text { yes } \\
\text { no }\end{array}$ & $5(0)$ & $7(70)$ & $<0.0001$ \\
\hline * median (range) & $25(96.2)$ & $3(30)$ & 0.009 \\
\hline *** Sebaceous hyperplasia, sebaceous adenoma and sebaceoma & $1(3.8)$ & $7(70)$ & \\
\hline
\end{tabular}

compared to benign sebaceous lesions. Using the cutoff point suggested by Cabral et al. ${ }^{8}$ that a p53 expression higher than $10 \%$ is associated to a sebaceous carcinoma diagnosis, we found that $70 \%$ of sebaceous carcinoma cases exhibited a p53 expression higher than $10 \%$. 


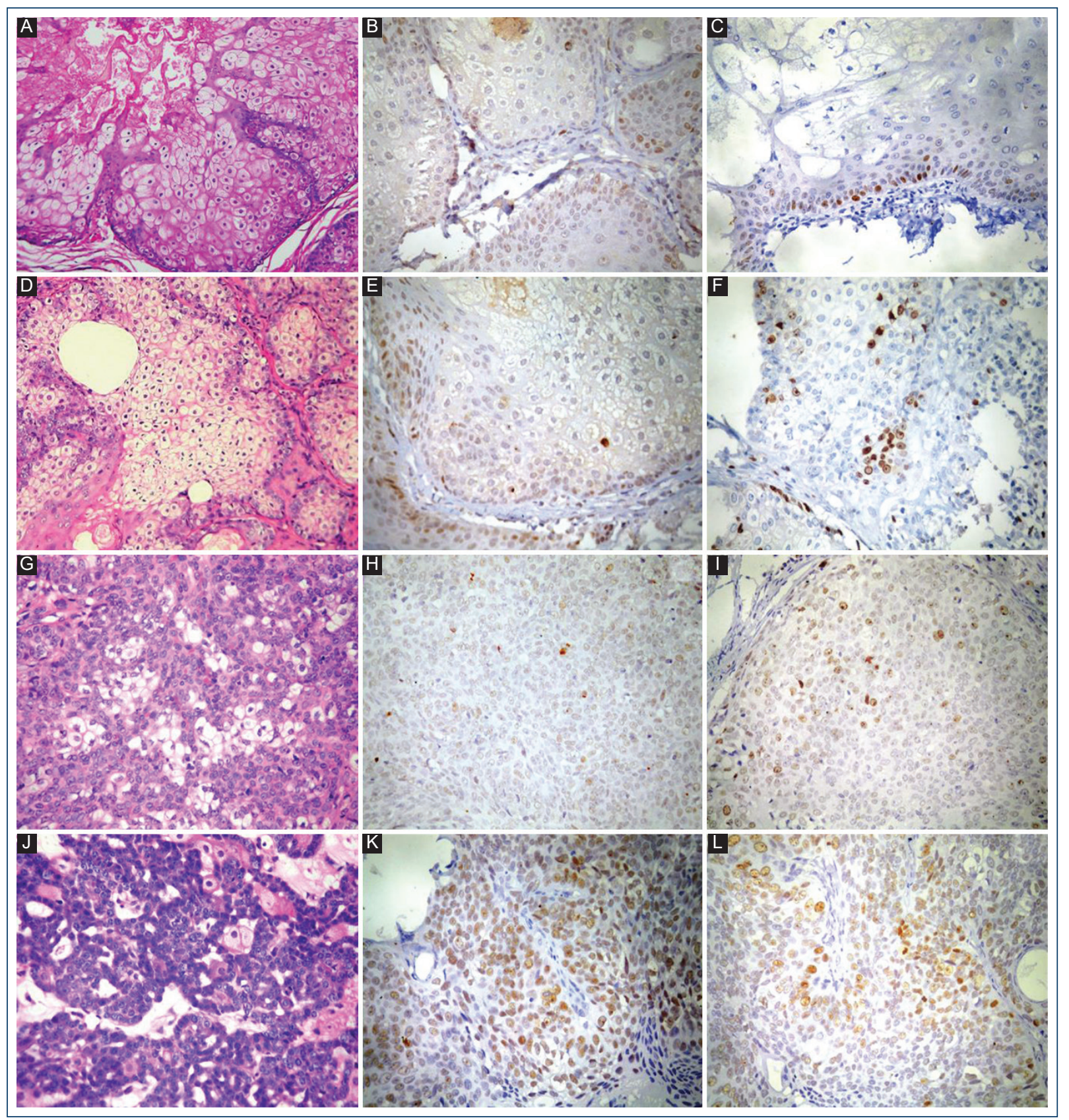

Figure 1. Sebaceous hyperplasia A: hematoxylin and eosin. B: p53. C: ki-67. Sebaceous adenoma D: hematoxylin and eosin. E: p53. F. Ki-67. Sebaceoma G: hematoxylin and eosin. H: p53. I. Ki-67. Sebaceous carcinoma J: hematoxylin and eosin. K: p53. L: ki-67.

Conversely, MKI67 is a protein that is expressed in the nucleus of all cells in the active phases of the cell cycle. The Ki-67 immunomarker is used to detect this protein. It has been observed that the higher the rate of Ki-67 proliferation, the greater the probability of a neoplasm being malignant ${ }^{35-38}$. This finding was corroborated by this study and allows us to infer that sebaceous carcinoma is a neoplasm, whose proliferative activity is increased with respect to benign sebaceous lesions. Statistical significance was found using a cutoff point for Ki-67 $>25 \%$ in the diagnosis of sebaceous carcinoma ${ }^{4}$. About $70 \%$ of sebaceous carcinoma cases were found to have a Ki-67 expression $>25 \%$. 


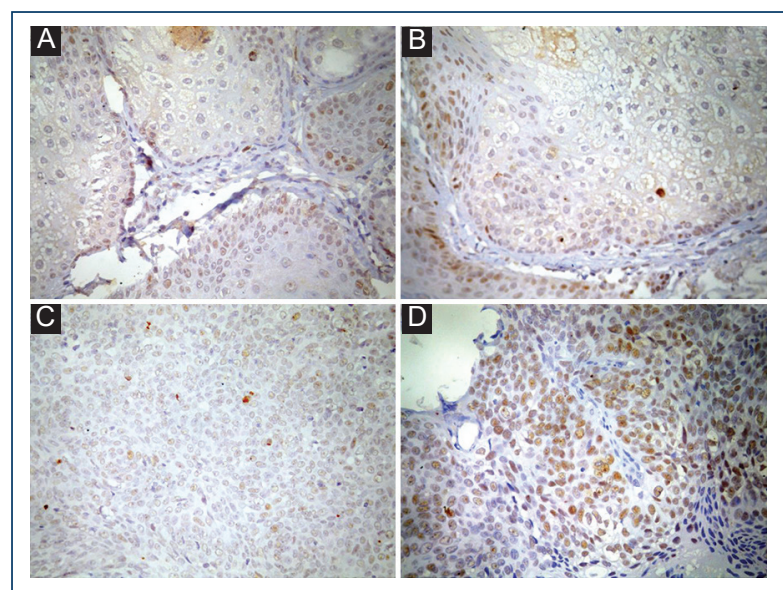

Figure 2. p53 expression. An increase in p53 expression is observed in sebaceous carcinoma compared to benign sebaceous lesions. A: sebaceous hyperplasia. B: sebaceous adenoma. C: sebaceoma. D: sebaceous carcinoma.

\section{Conclusion}

A p53 expression > 10\% and a Ki-67 expression $>25 \%$ are suggestive for the diagnosis of sebaceous carcinoma.

\section{Funding}

Existing hospital resources.

\section{Conflicts of interest}

The authors declare that there are no conflicts of interest.

\section{Ethical disclosures}

Protection of human and animal subjects. The authors declare that no experiments were performed on humans or animals for this study.

Confidentiality of data. The authors declare that they have followed the protocols of their work center on the publication of patient data.

Right to privacy and informed consent. The authors declare that no patient data appear in this article.

\section{References}

1. Requena L, Sangüeza O. Neoplasms with sebaceous differentiation. In: Requena L, Sangüeza O, editors. Cutaneous Adnexal Neoplasms. Switzerland: Springer; 2017. p. 754-973.

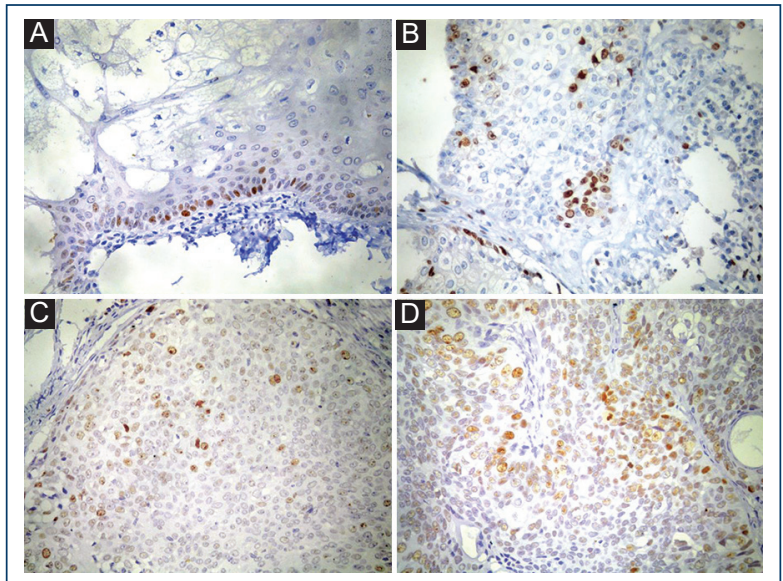

Figure 3. Ki-67 expression. An increase in the Ki-67expression is observed in sebaceous carcinoma compared to benign sebaceous lesions. A: sebaceous hyperplasia. B: sebaceous adenoma. C: sebaceoma. D: sebaceous carcinoma.

2. lacobelli J, Harvey NT, Wood BA. Sebaceous lesions of the skin. Pathology. 2017;49:688-97.

3. Ansai S. Topics in histopathology of sweat gland and sebaceous neoplasms. J Dermatol. 2017;44:315-26.

4. Dasgupta T, Wilson LD, Yu JB. A retrospective review of 1349 cases of sebaceous carcinoma. Cancer. 2009;115:158-65.

5. Valenzuela-Flores G, Mozas-Dávila D, Rodríguez-Reyes AA, Gómez-Leal A. Carcinoma de glándulas sebáceas de los párpados. Cir Ciruj. 2004;72:47-53

6. Kyllo RL, Brady KL, Hurst EA. Sebaceous carcinoma: a review of the literature. Dermatol Surg. 2015;41:1-15.

7. Shields JA, Demirci H, Marr BP, Eagle RC, Shields CL. Sebaceous carcinoma of the ocular region: a review. Surv Ophthalmol. 2005;50: 103-22.

8. Cabral ES, Auerbach A, Killian K, Barrett TL, Cassarino DS. Distinction of benign sebaceous proliferations from sebaceous carcinomas by immunohistochemistry. Am J Dermatopathol. 2006;28:465-71.

9. Harvey NT, Budgeo CA, Leecy T. Interobserver variability in the diagnosis of circumscribed sebaceous neoplasms of the skin. Pathology. 2013;45:581-6.

10. Obiec FA, Mendoza PR. Eyelid sebaceous carcinoma: clinicopathologic and multiparametric immunohistochemical analysis that includes adipophilin. Am J Ophthalmol. 2014;157:186-208.

11. Plaza JA, Mackinnon A, Carrillo L, Prieto VG, Sangueza M, Suster S. Role of immunohistochemistry in the diagnosis of sebaceous carcinoma: A clinicopathologic and immunohistochemical study. Am J Dermatopathol. 2015;37:809-21.

12. Harvey NT, Tabone T, Erber W, Wood BA. Circumscribed sebaceous neoplasms: a morphological immunohistochemical and molecular analysis. Pathology. 2016;48:454-62.

13. Ostler DA, Prieto VG, Reed JA, Deavers MT, Lazar AJ, Ivan D. Adipophilin expression in sebaceous tumors and other cutaneous lesions with clear cell histology: an immunohistochemical study of 117 cases. Mod Pathol. 2010;23:567-73.

14. Yang H, Cabral E, Dadras SS, Cassarino DS. Immunohistochemical expression of D2-40 in benign and malignant sebaceous tumors and comparison to basal and squamous cell carcinomas. Am J Dermatopathol. 2008;30:549-54.

15. Ansai S, Arase S, Kawana S, Kimura T. Immunohistochemical findings of sebaceous carcinoma and sebaceoma: retrieval of cytokeratin expression by a panel of anti-cytokeratin monoclonal antibodies. J Dermatol. 2011;38:951-8.

16. Mulay K, White VA, Shah SJ, Honavar SG. Sebaceous carcinoma: clinicopathologic features and diagnostic role of immunohistochemistry (including androgen receptor). Can J Ophthalmol. 2014;49:326-32.

17. Ni C, Searl SS, Kuo PK, Chu FR, Chong CS, Albert DM. Sebaceous cell carcinomas of the ocular adnexa. Int Ophthalmol Clin. 1982;22:23-61.

18. Kasakov DV, Michal M, Kacerovska D, McKee PH. Lesions with predominant sebaceous differentiation. In: Kasakov DV, Michal M, Ka- 
cerovska D, McKee PH, editors. Cutaneous Adnexal Tumors. United States: Lippincott Williams and Wilkins; 2012. p. 329-409.

19. Pereira PR, Odashiro AN, Rodrigues-Reyes AA, Correa ZM, de Souza Filho JP, Burnier MN Jr. Histopathological review of sebaceous carcinoma of the eyelid. J Cutan Pathol. 2005;32:496-501.

20. Misago N, Mihara I, Ansai S. Narisawa Y. Sebaceoma and related neoplasms with sebaceous differentiation: a clinicopathologic study of 30 cases. Am J Dermatopathol. 2002;24:294-304.

21. Shields JA, Demirci H, Marr BP, Eagle RC Jr., Shields CL. Sebaceous carcinoma of the eyelids: personal experience with 60 cases. Ophthalmology. 2004;111:2151-7.

22. Deprez M, Uffer S. Clinicopathological features of eyelid skin tumors. A retrospective study of 5504 cases and review of literature. Am J Dermatopathol. 2009:31:256-62.

23. Hussain RM, Matthews JL, Dobovy SR, Thompson JM, Wang G. UV-independent p53 mutations in sebaceous carcinoma of the eyelid. Ophthal Plast Reconstr Surg. 2014;30:392-5.

24. Kiyosaki K, Nakada C, Hijiya N, Tsukamoto Y, Matsuura K, Nakatsuka K, et al. Analysis of p53 mutations and the expression of p53 and p21 WAF/CIP protein in 15 cases of sebaceous carcinoma of the eyelid. Invest Ophthalmol. 2010;51:7-11.

25. Mercadillo-Pérez P, Moreno-López LM. Fisiopatología del carcinoma epidermoide. Dermatol Rev Mex. 2013;57:118-27.

26. Mello SS, Attardi LD. Deciphering p53 signaling in tumor suppression Curr Opin Cell Biol. 2018:51:65-72.

27. Liu J, Zhang C, Zhaohui F. Tumor suppresor p53 and its gain-of-function mutants in cancer. Acta Biochim Biophys Sin. 2014;46:170-9.
28. Benjamin CL, Ananthaswamy HN. p53 and the pathogenesis of skin cancer. Toxicol Appl Pharmacol. 2007;224:241-8.

29. Shalin SC, Sakharpe A, Lyle S, Lev D, Calonje E, Lazar AJ. p53 staining correlates with tumor type and location in sebaceous neoplasms. Am J Dermatopathol. 2012;34:129-38.

30. Lane D, Levine A. p53 research: the past thirty years and the next thirty years. Cold Spring Harb Perspect Biol. 2010;2:a000893.

31. Borresen-Dale AL. TP53 and breast cancer. Hum Mutat. 2003:21:292-300.

32. Toyooka S, Tsuda T, Gazdar AF. The TP53 gene, tobacco exposure, and lung cancer. Hum Mutat. 2003;21:229-39.

33. Gonzalez-Fernandez F, Kaltreider SA, Patnaik BD, Retief JD, Bao Y Newman S, Stoler MH, et al. Sebaceous carcinoma. Tumor progression through mutational inactivation of p53. Ophthalmology. 1998; 105:497-506.

34. Becker K, Goldberg M, Helmbold P, Holbach LM, Loeffler KU, Ballhausen WG. Deletions of BRCA1/2 and p53 R248W gain-of-function mutation suggest impaired homologous recombination repair in fragile histidine triad-negative sebaceous gland carcinomas. $\mathrm{Br} \mathrm{J}$ Dermatol. 2008:159:1282-9.

35. Scholzen T, Gerdes J. The Ki-67 protein: from the known and the unknown. J Cell Physiol. 2000;182:311-22.

36. Sun X, Kaufman PD. Ki-67: more than a proliferation marker. Chromosoma. 2018:127:174-86.

37. Menon SS, Guruvayoorappan C, Sakthivel KM, Rasmi RR. Ki-67 protein as a tumour proliferation marker. Clin Chim Acta. 2019;491:39-45.

38. Ansai S, Koseki S, Hozumi Y, Kondo S, Aso K. Assessment of cellular proliferation of sebaceous neoplasms by AgNOR counts and immunohistochemical demonstrations of PCNA and Ki-67. J Dermatol. 1995;22:238-48. 